\title{
A clinical study on the analysis of caesarean section rates using Robson's ten group classification in a tertiary care hospital
}

\author{
Priya Shankar, Madhu J.*, Vinay Raju
}

Department of Obstetrics and Gynecology, KIMS, Hubli, Karnataka, India

Received: 19 December 2018

Accepted: 02 January 2019

\section{*Correspondence:}

Dr. Madhu J.,

E-mail: madhuobg@yahoo.co.in

Copyright: () the author(s), publisher and licensee Medip Academy. This is an open-access article distributed under the terms of the Creative Commons Attribution Non-Commercial License, which permits unrestricted non-commercial use, distribution, and reproduction in any medium, provided the original work is properly cited.

\begin{abstract}
Background: Auditing c section rates can be done using Robson's classification which in turn helps achieve a uniform basis for comparison across centers and across various countries.

Methods: A retrospective analysis was done in a tertiary care hospital in north Karnataka KIMS, over a period of 6 months May 2017 to October 2017. All cases of LSCS done during this period were classified according to Robson's classification and analyzed.

Results: Out of 5080 overall deliveries 1876 delivered by cesarean section attributing to $36.76 \%$ cesarean section rate. Highest contribution was from group 5 (36\%) and group $2(19.24 \%)$.

Conclusions: Robson's classification helps to identify and analyze the group that contribute to the most to overall cesarean section rate and this helps us to modify strategies and interventions to optimize cesarean section rate.
\end{abstract}

Keywords: Caesarean section rate, Primary caesarean section, Robson's classification

\section{INTRODUCTION}

A caesarean section is a lifesaving surgical procedure that can prevent maternal and perinatal mortality and morbidity. Over the last decades, however the use of caesarean as a mode of delivery has been increasing to un precedential levels with parallel concerns about its consequences. ${ }^{1}$ This has raised a professional debate about appropriate indications for the operations. In 1985 WHO started caesarean section rate should be less than $15 \% .^{2-4}$ In order to understand what is driving this trend and to propose and implement effective measures to ensure that it is not being used unnecessarily, a tool to monitor and compare caesarean section rates in a same setting over time and between different settings is needed. In 2015, WHO proposed the use of the Robson classifications a global standard for assessing, monitoring and comparing caesarean section rates both with in health care facilities and between them. Women who give birth are categorized in to ten groups based on their basic obstetric characteristics of parity, previous CS, gestational age, mode of onset of labor, fetal presentation and number of fetuses. These groups are structured in such a way that they are mutually exclusive and totally inclusive. The Ten-Group Robson classification has been raised for its simplicity, robustness, reproducibility and flexibility and has been recommended for both the monitoring rates over time as well as between facilities by both WHO in 2014 and FIGO in 2016. ,6 $^{5}$ Robson's criteria helps us to compare the LSCS trends across the hospitals and around the globe because of uniformity on indications. In present tertiary hospital with an average of 10,000 women deliver per year. Over the years the percentage of LSCS has increased in present hospital as well as worldwide. In our government set up with limited resources auditing and revisiting the indications, rates, and outcome helps to best utilize our government resources for the help of the neediest. Rising trend in 
number of LSCS over the year has been a cause of concern.

\section{METHODS}

Retrospective study was done in KIMS hospital, Hubli a tertiary government medical center from $1^{\text {st }}$ May 2017 to $31^{\text {st }}$ October2017. It was a retrospective analysis done for women who delivered during this study period.

\section{Inclusion criteria}

- All patients delivered by LSCS were included and classified according to Robson's classification system (Table 1).

Each group relevant data on name, age, IP number, obstetric history, socioeconomic status, stage of labor, membrane status, previous obstetric history, single, multiple, term or preterm, examination findings at admission and LSCS were noted.

\section{Exclusion criteria}

- Term normal or instrumental vaginal delivery

- Preterm normal or instrumental vaginal delivery.

Data collected were analyzed using simple statistical measures like percentage and proportion.
Table 1: Robson's classification system.

\begin{tabular}{|c|c|}
\hline Group & Description \\
\hline 1 & $\begin{array}{l}\text { Nulliparous, single cephalic, } \geq 37 \text { weeks, } \\
\text { spontaneous labour }\end{array}$ \\
\hline $2 \mathrm{~A}$ & $\begin{array}{l}\text { Nulliparous, single cephalic, } \geq 37 \text { weeks, } \\
\text { induced labour }\end{array}$ \\
\hline $2 \mathrm{~B}$ & $\begin{array}{l}\text { Nulliparous, single cephalic, } \geq 37 \text { weeks, } \\
\text { caesarean before labour }\end{array}$ \\
\hline 3 & $\begin{array}{l}\text { Multiparous (excluding previous caesareans), } \\
\text { single cephalic, } \geq 37 \text { weeks, spontaneous labor }\end{array}$ \\
\hline $4 \mathrm{~A}$ & $\begin{array}{l}\text { Multiparous (excluding previous caesareans), } \\
\text { single cephalic, } \geq 37 \text { weeks, induced labor }\end{array}$ \\
\hline 4B & $\begin{array}{l}\text { Multiparous (excluding previous caesareans), } \\
\text { single cephalic, } \geq 37 \text { weeks, caesarean before } \\
\text { labor }\end{array}$ \\
\hline 5 & Previous caesarean, single cephalic, $\geq 37$ weeks \\
\hline 6 & All nulliparous breeches \\
\hline 7 & $\begin{array}{l}\text { All multiparous breeches (including previous } \\
\text { caesareans) }\end{array}$ \\
\hline 8 & $\begin{array}{l}\text { All multiple pregnancies (including previous } \\
\text { caesareans) }\end{array}$ \\
\hline 9 & $\begin{array}{l}\text { All abnormal lies (including previous } \\
\text { caesareans) }\end{array}$ \\
\hline 10 & $\begin{array}{l}\text { All single cephalic, } \leq 36 \text { weeks (including } \\
\text { previous caesareans) }\end{array}$ \\
\hline
\end{tabular}

\section{RESULTS}

In KIMS center, during study period of six months total number of deliveries were 5086 .

Table 2: Cesarean section rates among women groups according to Robson's 10 group classification.

\begin{tabular}{|c|c|c|c|c|c|}
\hline & $\begin{array}{l}\text { Number of } \\
\text { CS/ total } \\
\text { number of } \\
\text { women }\end{array}$ & $\begin{array}{l}\text { Relative } \\
\text { size of } \\
\text { group }\end{array}$ & $\begin{array}{l}\text { Cesarean } \\
\text { section rate } \\
\text { in each } \\
\text { group }\end{array}$ & $\begin{array}{l}\text { Contribution made by } \\
\text { each group to overall } \\
\text { cesarean section rate } \\
(36.88 \%)\end{array}$ & $\begin{array}{l}\text { Relative } \\
\text { contribution made } \\
\text { by each group for } \\
\text { CS ( } n=1876)\end{array}$ \\
\hline $\begin{array}{l}\text { Nulliparous single cephalic } \geq 37 \\
\text { weeks in spontaneous labor }\end{array}$ & $332 / 900$ & $\begin{array}{l}900 / 5086 \\
(17.69 \%)\end{array}$ & $\begin{array}{l}36.8 \% \\
(332 / 900)\end{array}$ & $\begin{array}{l}6.5 \% \\
(332 / 5086)\end{array}$ & $\begin{array}{l}17.69 \% \\
(332 / 1876)\end{array}$ \\
\hline $\begin{array}{l}\text { Nulliparous single cephalic } \geq 37 \\
\text { weeks induced/ CS before labor }\end{array}$ & $361 / 460$ & $\begin{array}{l}460 / 5086 \\
(9.04 \%)\end{array}$ & $\begin{array}{l}74.82 \% \\
(361 / 460)\end{array}$ & $\begin{array}{l}7.09 \% \\
(361 / 5086)\end{array}$ & $\begin{array}{l}19.24 \% \\
(361 / 1876)\end{array}$ \\
\hline $\begin{array}{l}\text { Multiparous excluding previous } \\
\text { LSCS, single cephalic } \geq 37 \text { weeks } \\
\text { in spontaneous labour }\end{array}$ & $116 / 373$ & $\begin{array}{l}370 / 5086 \\
(7.29 \%)\end{array}$ & $\begin{array}{l}31.09 \% \\
(116 / 373)\end{array}$ & $\begin{array}{l}2.28 \% \\
(116 / 5086)\end{array}$ & $\begin{array}{l}6.1 \% \\
(116 / 1876)\end{array}$ \\
\hline $\begin{array}{l}\text { Multiparous excluding previous } \\
\text { LSCS } \geq 37 \text { weeks, induced/cs } \\
\text { before labor }\end{array}$ & $132 / 607$ & $\begin{array}{l}607 / 5086 \\
(11.93 \%)\end{array}$ & $\begin{array}{l}21.7 \% \\
(132 / 607)\end{array}$ & $\begin{array}{l}2.59 \% \\
(132 / 5086)\end{array}$ & $\begin{array}{l}7 \% \\
(132 / 1876)\end{array}$ \\
\hline $\begin{array}{l}\text { Previous LSCS single cephalic } \\
\geq 37 \text { weeks }\end{array}$ & $684 / 812$ & $\begin{array}{l}812 / 5086 \\
(15.96 \%)\end{array}$ & $\begin{array}{l}84.2 \% \\
(684 / 812)\end{array}$ & $\begin{array}{l}13.44 \% \\
(684 / 5086)\end{array}$ & $\begin{array}{l}36 \% \\
(684 / 1876)\end{array}$ \\
\hline All nulliparous breeches & $34 / 45$ & $\begin{array}{l}45 / 5086 \\
(0.86 \%)\end{array}$ & $\begin{array}{l}75.5 \% \\
(34 / 45)\end{array}$ & $\begin{array}{l}0.66 \% \\
(34 / 5086)\end{array}$ & $1.8 \%$ \\
\hline $\begin{array}{l}\text { All multiparous breech } \\
\text { (including previous LSCS) }\end{array}$ & $40 / 99$ & $\begin{array}{l}99 / 5086 \\
(1.94 \%)\end{array}$ & $\begin{array}{l}40.4 \% \\
(40 / 99)\end{array}$ & $\begin{array}{l}0.78 \% \\
(40 / 5086)\end{array}$ & $\begin{array}{l}2.1 \% \\
(40 / 1876)\end{array}$ \\
\hline $\begin{array}{l}\text { All multiple pregnancy } \\
\text { (including previous LSCS) }\end{array}$ & $36 / 102$ & $\begin{array}{l}102 / 5086 \\
(2.005 \%)\end{array}$ & $\begin{array}{l}35.29 \% \\
(36 / 102)\end{array}$ & $\begin{array}{l}0.70 \% \\
(36 / 5086)\end{array}$ & $\begin{array}{l}1.9 \% \\
(36 / 1876)\end{array}$ \\
\hline $\begin{array}{l}\text { All abnormal lie } \\
\text { (including previous LSCS) }\end{array}$ & $28 / 28$ & $\begin{array}{l}28 / 5086 \\
(0.55 \%)\end{array}$ & $\begin{array}{l}100 \% \\
(28 / 28)\end{array}$ & $\begin{array}{l}0.55 \% \\
(28 / 5086)\end{array}$ & $\begin{array}{l}1.49 \% \\
(28 / 1876)\end{array}$ \\
\hline $\begin{array}{l}\text { All single cephalic } \leq 36 \text { weeks } \\
\text { including previous LSCS) }\end{array}$ & $113 / 421$ & $\begin{array}{l}421 / 5086 \\
(8.27 \%)\end{array}$ & $\begin{array}{l}26.84 \% \\
(113 / 421)\end{array}$ & $\begin{array}{l}2.2 \% \\
(113 / 5086)\end{array}$ & $\begin{array}{l}6.02 \% \\
(113 / 1876)\end{array}$ \\
\hline
\end{tabular}


Total numbers of women delivered by LSCS were 1876 attributing to $36.88 \%$ LSCS rate. Data of women who delivered by LSCS during this period were analyzed using Robson's classification (Table 2).

Greatest contributors were group 5 with relative contribution of $36.4 \%$ with $84.2 \%$ CS rate (684/812) suggesting less VBAC trial or more of referred previous LSCS cases. Though group 5 has the highest number of sections in present study relative size of the group is $15.9 \%$, suggesting that previous years had lesser LSCS rate in present institute.

Second contribution was group 2 with relative contribution of $19.2 \%$ with $74.82 \%$ CS rate (361/406). This can be attributed to higher number of referral cases and failed induction. High C-section rate in group 2 needs revisiting and analysis. Though relative size of group 2 was less $(9 \%)$ as compared to other studies C- section rate was high.

The third contribution was from group 1 with relative group size of $17.69 \%$ and CS rate of $36.8 \%$. Relative contribution of multiparous group excluding previous LSCS was $13.1 \%$. C-section rate in group 6 was $75.5 \%$, as in present institute $\mathrm{C}$ section done for all primigravida with term breech if baby is salvageable. CS rate in group 9 was $100 \%$, but relative contribution was low (1.49\%).

\section{DISCUSSION}

Groups were interpreted according to Robson's criteria. All groups were analyzed clinically according to Robson's criteria. The section rate in present institute was found to be $36 \%$ which is higher as compared to the WHO given guideline of $15 \%$ cesarean rate.

Group 5 contributed highest number of $\mathrm{C}$ Section in present study which was $36.4 \%$ because of increased referral and increase primary section, which was almost similar to the study conducted by Wanjari SA et al, while in the studies conducted by Shirsath A et al and Kansara Vijay et al, the caesarean rates of this group was quite high i.e., $54.5 \%$ and $46.2 \%$ respectively. ${ }^{7-9}$

Present group 1 and 2 together contributed $26.7 \%$ which is lesser than other usual numbers quoted by other studies like Kotreshwara $S$ et al where the group 2 contributed to around $32.2 \%$, which was the leading group in their study. ${ }^{10}$ Ratio of group 1 and group 2 (17.5\% vs $\left.19 \%\right)$ shows that incidence of induction of labor is more but success rate was relatively less with induction.

Choosing right cases for induction of labor will help decrease the cesarean section rate which was contributing $26.24 \%$ (primi and multi) to overall rate. The areas for reanalysis for failed induction would be method of induction, drugs used, strictly reassessing referral induced cases, choosing right cases for induction of labor, and quality of drugs.
Group 3 and 4 contributed to around $11 \%$ which similar to the study conducted by Kotreshwara $\mathrm{S}$ et al. ${ }^{9}$ Group 3 and $4(11.94 \%$ and $7.29 \%)$ combined has a relative size of $20 \%$, though our induction is higher the success rate is less. Relative size of group 5 was $15.9 \%$ suggesting previous low CS rate. Group 6 and group 7 contributed to $<4 \%$ of C Section rates which was comparable with other studies.

Group 9 was $0.55 \%$ in relative size and $\mathrm{C}$ section rate was $100 \%$ as sections are done for all abnormal lies in present institute at term. Group $10 \mathrm{C}$ section was $8.27 \%$ relative size which is well within accepted range.

\section{CONCLUSION}

Robson criteria helps in analysis as well as putting in perspective the number of LSCS done and group which contributes maximum. This classification helps us to focus on certain groups to reduce $\mathrm{C}$-section rate. It also helps us to reanalyse our protocols for reducing $\mathrm{C}$-section rate.

\section{Funding: No funding sources}

Conflict of interest: None declared

Ethical approval: The study was approved by the Institutional Ethics Committee

\section{REFERENCES}

1. Maternal perinatal Robson classification implementation. Available at: https://www.who.int/reproductivehealth/topics/mater nal_perinatal/robson-clossificationimplementatin/en/.

2. WHO. Appropriate technology for birth. Lancet 1985;2:436-7.

3. Villar J, Carroli G, Zavaleta N, Donner A, Wojdyla D, Faundes A, et al. Maternal and neonatal individual risks and benefits associated with caesarean delivery: Multicentre prospective study. BMJ. 2007;335(7268):1025

4. Villar J, Valladares E, Wojdyla D, Zavaleta N, Carroli G, Velazco A, et al. Caesarean delivery rates and pregnancy outcomes: The 2005 WHO global survey on maternal and perinatal health in Latin America. Lancet. 2006;367(9525):1819-29.

5. Betran AP, Vindevoghel N, Souza JP, Guelmezoglu AM, Torloni MR. A systematic review of the Robson classification for caesarean section: what works, doesn't work and how to improve it. PloS One. 2014;9(6):e97769.

6. Figo WG, Care OM. Best practice advice on the 10Group Classification System for cesarean deliveries. Int $\mathrm{J}$ Gynaecol Obstet: the official organ of the Int Fed Gynaecol Obstet. 2016;135(2):232-3.

7. Wanjari SA. Rising caesarean section rate: a matter of concern?. Int J Reprod Contracept Obstet Gynecol. 2014;3:728-31. 
8. Shirsath A, Risbud N. Analysis of cesarean section rate according to Robson's 10-group classification system at a tertiary care hospital. Int $\mathbf{J}$ Sci Res. 2014;3(1):401-2.

9. Kansara V, Patel S, Aanand N, Muchhadia J, Kagathra B, Patel R. A recent way of evaluation of cesarean birth rate by Robson's 10-group system. J Med Pharma Allied Sci. 2014;01:62-70.

10. Koteshwara S, Sujatha MS. Analysis of caesarean section rates using Robsons ten group classification: the first step. Int J Reprod Contracept Obstet Gynecol. 2017;6:3481-5.

Cite this article as: Shankar P, Madhu J, Raju V. A clinical study on the analysis of caesarean section rates using Robson's ten group classification in a tertiary care hospital. Int J Reprod Contracept Obstet Gynecol 2019;8:488-91. 